\title{
A büntetés-végrehajtás alapelve(i) ${ }^{1}$
}

\section{JUHÁSZ Zsuzsanna²}

\begin{abstract}
A normalizáció alapelve az Európai Börtönszabályokban rögzített emberi jogi elv és számos ország, különösen a skandináv börtönrendszerek alapértéke. Az alapelv az jelenti, hogy a hatóságok nem avatkozhatnak be a fogvatartottak életébe annál jobban, mint az a börtönkörnyezetben szükséges, illetve igényli, hogy a hatóságok tevékenyen teremtsenek olyan feltételeket, amelyek - amennyire csak lehetséges - hasonlítanak a szabad társadalomban lévőhöz. Néhány megközelítésben a normalizáció koncepciója azt is jelenti, hogy a börtönhatóságoknak kell elösegíteniük az egyes fogvatartottak törekvését arra, hogy a végrehajtás alatt megvalósítsák saját "normalitásukat”. De milyen korlátozásokat foglal magában a személyi szabadság elvonása, és mi tekinthető normálisnak egy végrehajtási intézetben, illetve a kinti társadalomban? A jelen írás ezeket a kérdéseket vizsgálja az elmélet, illetve a gyakorlat oldaláról.
\end{abstract}

Kulcsszavak: normalizáció, alapelvek, börtönlét, polgári jogok

\section{Bevezetés}

A büntetés-végrehajtási alapelvek olyan elvi tételek, amelyek a büntetés-végrehajtás rendszerét, múködését áthatják, a börtönügy szellemiségét meghatározzák, és jogi, morális, szakmai zsinórmértékül szolgálnak. Jelen írás a demokratikus alapon felépülő és múködő börtönrendszerek egyik központi, hangsúlyos alapelvét a normalizációt mutatja be, amely számos más alapelvet, így a felelősség, a nyitottság, a reintegráció, a humanizmus, a káros hatások minimalizálásának elvét, az emberi jogok tiszteletben tartásának követelményét egyaránt maga után vonja, azokkal szoros kapcsolatban áll.

\section{A normalizáció alapelvének lényegi elemei}

A normalizáció elvének kiindulópontja, hogy a személyi szabadság elvonása már önmagában véve büntetés, ezért ezt a büntetést és a bebörtönzéssel szükségszerűen együtt járó káros hatásokat nem szabad fokozni. Az alapelv értelmében - annak érdekében,

\footnotetext{
A kutatást az EFOP-3.6.2-16-2017-00007 azonosító számú, Az intelligens, fenntartható és inkluzív társadalom fejlesztésének aspektusai: társadalmi, technológiai, innovációs hálózatok a foglalkoztatásban és a digitális gazdaságban címú projekt támogatta. A projekt az Európai Unió támogatásával, az Európai Szociális Alap és Magyarország költségvetése társfinanszírozásában valósul meg.

2 JUHÁSZ Zsuzsanna, dr. habil., PhD, egyetemi docens, SZTE ÁJK, Bűnügyi Tudományok Intézet

Zsuzsanna JUHÁSZ, PhD, associate professor, University of Szeged, Faculty of Law and Political Science, Institute of Criminal Sciences

https://orcid.org/0000-0002-0679-3449, juhaszzs@juris.u-szeged.hu
} 
hogy a fogvatartottat további hátrányok ne érjék, a szabadságvesztés szükségszerủ káros hatásai enyhüljenek, a prizonizáció ellensúlyozható legyen - a végrehajtási életfeltételeket, a végrehajtási környezetet a lehetőségekhez mérten közelíteni kell a szabad élet körülményeihez, közegéhez. Nem arról van szó ugyanakkor, hogy pontosan olyan körülményeket teremtsünk, mint a végrehajtási intézet falain kívüli életben, hanem olyan feltételeket, amelyek ahhoz a legközelebb állnak. ${ }^{3}$ Tekintettel ugyanis arra, hogy a végrehajtási közegben alapvető jelentősége van a rend, a biztonság fenntartásának, az ezt biztosító eszközök és intézkedések alkalmazásának, a szabad élet reprodukálása, börtönkörnyezetbe átültetése teljes egészében nem kivitelezhető.

Yngve Hammerl megközelítésében ${ }^{4}$ a normalizáció fogalma tisztázatlan, mivel kérdésként merülhet fel, hogy a fogvatartottat, vagy magát a börtönkörnyezetet kell-e normalizálni. A szerző utal arra, hogy Norvégiában történetileg az intézményi cél például a fogvatartottak gondolkodásmódjának, szemléletének a normalizációját jelentette elsősorban kognitív módszerekkel. Ez azonban felveti annak az etikai dilemmáját, hogy a különféle támogató és védő intézkedések alkalmazása mellett meddig mehet el a végrehajtás, mielőtt átlépné a fogvatartottak személyes integritásának határát. Erre tekintettel fogalmaz úgy Hammerl, hogy erkölcsileg jobban védhető, ha a normalizáció az életkörülményekre, a végrehajtási feltételekre irányul.

Hans Jørgen Engbo nyomán ${ }^{5}$ különbség tehető defenzív és proaktív normalizáció között. A skandináv börtönügyi szakember szerint a defenzív megközelítés azt jelenti, hogy a hatóságok nem avatkozhatnak be a fogvatartott életébe annál nagyobb mértékben, mint ami a börtönkörnyezetből, a bebörtönzés tényéből fakadóan szükséges. Erre utal, hogy a dán, illetve a svéd szabályozás egyaránt lefekteti, miszerint a mozgási szabadság megvonásán kívül a szabadságvesztés-büntetés nem érinthet más szabadságot, illetve jogot. Elviekben tehát a mozgási szabadságot érintő beavatkozáson kívül a fogvatartottak bebörtönzésük során csak olyan beavatkozásokat kellene hogy elszenvedjenek, amelyek a bűnmegelőzési törekvésekkel, a biztonsági követelményekkel kapcsolatosak. Ezzel a be nem avatkozási kötelezettséggel szemben a proaktív megközelítés a hatóságok aktív cselekvésre irányuló kötelezettségét határozza meg: olyan feltételek, körülmények megteremtését, amelyek - amennyire csak lehetséges - megközelítik a börtönön kívülieket, ezzel bátorítva a fogvatartottakat, hogy „normális” életet éljenek.

Engbo megkülönböztetését alapul véve a normalizáció tehát nem pusztán a szabad társadalomban érvényesülő életfeltételekhez közelítő börtönkörnyezetként írható le, hanem annak fontos elemét képezi a szabadságelvonás által nem érintett jogok elismerése és biztosítása is. A börtönökön belüli élet normalizálásának egyik módozataként jelenik meg így a fogvatartottak jogi helyzetének elismerése.

\footnotetext{
Hazai szabályozásunkban erre tekintettel fogalmaz úgy a Bv. tv. 83. §-ának (4) bekezdése, hogy törekedni kell az elítélt életkörülményeinek szabad élet általános körülményeihez történő közelítésére.

Hammerl (2018) 260-262.

Engbo (2017) 328-329.
} 
Mindamellett a fogvatartottak életkörülményeinek normalizálásán, jogi helyzetének elismerésén kívül a normalizáció egy harmadik területet is érinthet, ez pedig a fogvatartottak személyes életének, személyes fejlődésének a normalizációja. Utóbbi arra irányul, hogy a fogvatartott maga normalizálja életét, szabadon döntsön a saját életvitelét illetően, azaz ne a hatóság határozza meg helyette, hogy számára mi a „normális”. ${ }^{6}$ Mindez előrevetíti a felelősség elvét: a fogvatartott kapjon lehetőséget arra, hogy felelősséget vállaljon, felelősen döntsön.

\section{Normalizáció a nemzetközi instrumentumokban és nemzeti dokumentumokban}

A normalizáció elvének megjelenése kapcsán az ENSZ által 1955-ben elfogadott Fogvatartottakkal való bánásmódra vonatkozó ENSZ minimum standard szabályokat ${ }^{7}$ kell elsőként megemlíteni, amely hosszú időn keresztül nemzetközi színtéren az egyetlen olyan dokumentum volt, amely közvetlenül foglalkozott a börtönstandardokkal és a börtönpolitikával. E szabálygyưjtemény alapján a végrehajtási intézetek szellemiségét át kell hassa az arra való törekvés, hogy minimalizálják a börtönlét és a szabad élet közötti mindazon eltéréseket, amelyek a fogvatartottak felelősségének vagy emberi méltóságuk elismerésének csökkentésére irányulnak.

Az ENSZ minimum standard szabályok európai feltételek közé történő adaptálása 1973-ban történt meg az Európa Tanács Miniszteri Bizottsága által elfogadott Fogvatartottakkal való bánásmód standard minimum szabályai ${ }^{8}$ elnevezésû dokumentummal, amely hasonló tartalommal vette át és hirdette a normalizáció elvét. E határozatot váltotta aztán fel 1987-ben a Miniszteri Bizottság által elfogadott Európai Börtönszabályok. ${ }^{9} \mathrm{Ez}$ az ajánlás tulajdonképpen továbbfejlesztette az alapelvet akként, hogy megfogalmazta a szabadságvesztés káros hatásainak és a börtönbeli, valamint a kinti élet közötti azon eltérések minimalizálásának szükségességét, amelyek a fogvatartottak önbecsülésének vagy személyes felelősségérzetének csorbítására irányulnak.

A normalizáció alapelvét a megújított és jelenleg is irányadó Európai Börtönszabályok $^{10}$ is megfogalmazza mint az egész európai börtönügy szellemiségét meghatározó, a szabálygyüjtemény egységes egészként való interpretációját és végrehajtását vezérlő elvek egyikét. Az ajánlás alapján a normalizáció elve alatt a börtönön kívüli közösségi élet pozitív aspektusaihoz lehető legjobban közelítő börtönfeltételek megteremtését kell érteni. Az alapelv ilyenformán nem egyszerúen a szabad életkörülményekhez leginkább közelítő végrehajtási környezet biztosítását kívánja meg a tagállamoktól, hanem a hangsúly a pozitív aspektusokra helyeződik. Az Európai Börtönszabályok kommen-

\footnotetext{
Engbo (2017) 336; 342.

Standard Minimum Rules for the Treatment of Prisoners. Adopted by the First United Nations Congress on the Prevention of Crime and the Treatment of Offenders, held at Geneva in 1955, and approved by the Economic and Social Council by its resolutions 663 C (XXIV) of 31 July 1957 and 2076 (LXII) of 13 May 1977, 60 (1).

8 Resolution (73) 5 on the standard minimum rules for the treatment of prisoners.

9 Recommendation No. R (87)3 on the European Prison Rules.

10 Recommendation No. R (2006)2. European Prison Rules.
} 
tárja ${ }^{11}$ ezzel kapcsolatban arra utal, hogy a börtönlét sohasem lehet azonos a szabad élettel, de aktív lépéseket kell tenni annak érdekében, hogy a normalizáció ne vezessen embertelen börtönfeltételekhez. Ennek háttere, hogy a szabad társadalomban jelentkező szociális problémák (például az élelmiszerek, gyógyszerek hiánya) a végrehajtási közegben embertelen börtönfeltételeket is eredményezhetnek. Kívánalom lehet tehát, hogy a szabad élethez közelítés ne érje el se az embertelen, se a megalázó bánásmód szintjét. $^{12}$

Az ajánlás egyúttal meghatározza a normalizáció defenzív követelményét is, amikor kimondja, hogy a személyi szabadságuktól megfosztott személyek mindazon jogai megmaradnak, amelyeket a törvény szerint az ítélettel vagy az őrizetbe helyezésüket kimondó határozattal nem vontak el tőlük (2. pont), illetve rögzíti, hogy a szabadságvesztés a szabadságelvonás által már önmagában véve büntetés, ezért az elítéltek rezsimje nem súlyosbíthatja a szabadságelvonással együtt járó szenvedést (102.2. pont). A szabálygyưjteményből kiolvasható tehát a törvényesség követelménye, amely abban ölt testet, hogy csak a törvény által előírt jogkorlátozások alkalmazhatók, egyebekben a szabadságvesztés-büntetést vagy őrizetet, letartóztatást kimondó határozattal jogszerüen el nem vont jogok a fogva tartás alatt is megilletik az érintetteket.

Noha e dokumentum „csak” ajánlás, azaz a soft-law kategóriájába tartozik, a kötelező jogi erő hiánya ellenére a többi ajánlással ${ }^{13}$ együtt szükségszerűen hatással bír a tagállamok jogalkotására és gyakorlatára. A jogalkotást tekintve például számos ország nemzeti joganyaga, végrehajtási kódexe tartalmazza az alapelvet (így többek között Finnország, Dánia, Svédország, Norvégia, Svájc, Németország és immáron hazánk szabályozása is) mégpedig kifejezésre juttatva az elv összetettségét, sokszínűségét.

Finnországban a szabadságvesztésről szóló törvény fogalmazza meg a normalizáció követelményét, amely egyaránt tartalmazza a proaktív és a defenzív megközelítést. Így a jogszabály alapján a börtönfeltételeket amennyire csak lehetséges a társadalom életfeltételeinek megfelelően kell megszervezni. A defenzív követelmény pedig akként jelenik meg, hogy ugyanezen jogszabály alapján a szabadságelvonó ítélet végrehajtása csak olyan korlátozásokat eredményezhet a fogvatartott helyzete, illetve jogai tekintetében, amelyeket jogszabály határoz meg, vagy önmagában a büntetés miatt szükségesek.

Dániában a büntetés-végrehajtási törvény alapján a fogvatartottaknak joguk és kötelezettségük a munkavégzés és/vagy a részvétel az oktatási programokban, illetve bármely más, a börtönadminisztráció által jóváhagyott programban. Ez azt jelenti, hogy a fogvatartott jogosult eldönteni, hogy melyiket választja. Választásától függetlenül pénzbeli juttatásban részesül, mégpedig akkor is, ha megbetegszik, vagy a fogva tartó intézet nem tud munkalehetőséget biztosítani számára, ami ugyancsak igazolja, alátámasztja

\footnotetext{
European Prison Rules. Council of Europe Publishing, Council of Europe, June 2006, 42.

Vö.: Van Zyl Smit - Snacken (2009) 103.

13 Itt jegyeznénk meg, hogy a normalizáció alapelve nevesítve megjelenik még a Miniszteri Bizottság életfogytig tartó szabadságvesztésre és más hosszú tartamú szabadságvesztésre ítéltek büntetés-végrehajtási intézetek általi irányításáról címet viselő R (2003) 23. ajánlásában is. Rec(2003)23E / 9 October 2003 Recommendation of the Committee of Ministers to member states on the management by prison administrations of life sentence and other long-term prisoners.
} 
a szociálpolitika, illetve a büntetőpolitika kapcsolatát. A normalizáció alapelve abban is megnyilvánul, hogy a fogvatartottak felelősek lakóterületük tisztántartásáért. ${ }^{14}$

Emellett a Büntetés-végrehajtási és Pártfogó Felügyelői Szolgálat Alapelveinek Programja elnevezésű dokumentum a normalizációval összefüggésben a börtönbeli életre, illetve a mindennapi életre fókuszál, amikor a szolgálat számára a mindennapok, illetve egyes specifikus döntések meghozatala kapcsán a szabad élet feltételeinek, körülményeinek szem előtt tartását követelményként rögzíti. ${ }^{15} \mathrm{~A}$ hivatkozott program egyik fő szerzője William Rentzmann ezt akként fogalmazta meg, hogy minden a börtönben felmerülő, megoldásra váró kérdés kapcsán abból kell kiindulni, azt hogyan, miként oldanánk meg a szabad társadalomban, illetve van-e bármi különös oka annak, hogy másként cselekszünk. ${ }^{16}$

A dán büntetés-végrehajtás így a normalizáció folyományának tekinti, hogy a személyi állomány mind öltözködésében, viselkedésében és beszédében támogassa az egészséges társadalmi kapcsolatokat a fogvatartottakkal. Az alapelv érvényesülését szolgálja az is, hogy a szolgálat igyekszik biztosítani azokat a lehetőségeket, amelyeket a szabad polgárok is élvezhetnek például az oktatás, a szakképzés, a munkavégzés, az egészségügyi ellátás, a kulturális, illetve szabadidős tevékenységek kapcsán. ${ }^{17}$

Emellett az alapelv annyira tág, összetett, avagy annyi más elvet, kívánalmat is magában foglal, hogy célszerűségből leválasztották róla például a nyitottság és a felelősség elvét. Így az alapelv tartalmazza többek között, hogy a fogvatartottak is részesülnek az igazságosság és a méltányosság általános társadalmi garanciáiból, illetve a szabadságvesztés természetére tekintettel esetükben speciális szükséglet ezen garanciák biztosítása. Az alapelv emellett azt is jelenti, hogy a végrehajtási intézetek fizikai kondícióit a szabad társadalomban fennállókkal kell rokonítani és egyúttal módosítani, a külvilágban esetlegesen bekövetkező változások nyomán. ${ }^{18}$

A svéd szabadságvesztésről szóló törvény alapján ebben a skandináv országban a normalizáció hangsúlyos eleme a szabadság, mivel a jogszabály alapján a fogvatartott szabadságának elvonása nem vonhat maga után más korlátozást, csak olyat, amit e hivatkozott törvény tartalmaz, vagy amely a jó rend, illetve a biztonság fenntartásához szükséges.

A parányi Izland végrehajtási törvénye ugyan nem tartalmaz általános rendelkezést a normalizáció kapcsán, de az elv létezése a fogvatartottak egészségügyi ellátásával foglalkozó részből egyértelműen kiolvasható. A jogszabály alapján ugyanis a fogvatartottak számára a társadalomban alkalmazottal egyenértékű egészségügyi ellátást, szolgáltatást kell biztosítani. ${ }^{19}$

\footnotetext{
4 Schartmueller (2015) 166-167.

Engbo (2017) 329-330.

Reintzmannt idézi és hivatkozza: Engbo (2017) 338.

17 Response of the government of Denmark to note cu 2011/26., 17. Forrás: www.unodc.org/documents/justice-andprison-reform/EGM-Uploads/DENMARK-GOV-13-En.pdf (2018. 05. 03).

18 Response of the government of Denmark to note cu 2011/26., 10.

19 Engbo (2017) 329-332.
} 
Izlandhoz hasonlóan a norvég végrehajtási törvény sem rendelkezik a normalizációról, mégis, ahogy arra többek között Engbo rámutat, mind az elméletben, mind pedig a gyakorlatban nagy jelentőséggel bír. A norvég büntetés-végrehajtás egykori parancsnoka Kristin Bølgen Bronebakk ${ }^{20}$ maga is úgy fogalmazott, hogy a normalizáció alapelve a büntetés-végrehajtási szervezet egyik alappillére, amely igényli, hogy a fogvatartottaknak megmaradjanak mindazon jogaik, amelyeket a bebörtönzés ténye nem von el szükségszerúen. Bronebakk szerint az elv hasonló kereteket enged a fogvatartottak személyes fejlődésének, mint tenné azt a szabad polgárok vonatkozásában.

Bronebakkhoz hasonlóan Gerhard Ploeg ${ }^{21}$ is a norvég büntetés-végrehajtás sarkalatos pontjaként írja le az alapelvet, amelynek három fő kihatásáról tesz említést. Egyrészről utal arra, hogy a szabadság korlátozásán túlmenően a polgárokhoz hasonlóan bír a fogvatartott is jogokkal, jogosultságokkal. Ezen jogok elutasításának alapja lehet az intézeti rend, illetve biztonság, de a végrehajtásnak magyarázattal kell szolgálnia az elutasítás okára nézve. Másrészről a biztonsági feltételeket a lehető legalacsonyabb szinten kell tartani és amennyiben nem áll fenn újabb büncselekmény elkövetésének, jogsértés okozásának a kockázata, akkor az ítéletet alacsony biztonsági fokozatú végrehajtási intézetben kell megkezdeni. Harmadsorban pedig a végrehajtás alatti életmenetet, a végrehajtási körülményeket a lehetőségekhez mérten hasonlítani kell a „normális” mindennapi élethez.

Engbo tanulmányában a norvég kormánynak a norvég parlamenthez intézett 2008as jelentését ${ }^{22}$ is hivatkozza, amely ugyancsak foglalkozott a normalizáció alapelvével, és azt a reintegráció eszközeként írta körül. A jelentés alapján ugyanis az alapelv a bebörtönzés tartama alatt igényli a társadalomba történő visszailleszkedésre való felkészítést. Maga az átállás pedig a végrehajtási környezetből a szabad életbe annál zavartalanabb, minél kisebb az eltérés a börtön közege és a kinti lét között. Az elv biztosítása érdekében ezért a végrehajtás mindennapi életét úgy kell megszervezni, hogy az a lehető legnagyobb mértékben visszatükrözze a szabad társadalmat. A jelentés kiemeli, hogy a normalizáció ezáltal az ítélet-végrehajtási politika alapelve.

Svájc Szövetségi Igazságügyi és Rendőri Minisztériumának 2010-es kiadványa a büntetés és intézkedések végrehajtásáról ${ }^{23}$ a börtönök életének normalizációját a büntetőpolitika általánosan elfogadott és alapvető jelentőségű elemeként írja le, ami a mindennapi börtönlét feltételeinek a szabad élethez való közelítéseként értelmezendő, különös tekintettel azon fogvatartotti igényekre, szükségletekre, amelyek a valós világban is fellelhetők, azzal összeegyeztethetők. A dokumentum alapján ezért a börtönök mindennapi életét a társas viselkedésmódok figyelembevételével, alkalmazásával kell megszervezni, így teremtve megfelelő feltételeket a szabaduláshoz. A kiadvány arra is utal, hogy figyelemmel kell lenni a normalizáció korlátaira, tekintve, hogy a szabad lét teljes egészében nem reprodukálható a börtönkörnyezetben. Erre tekintettel

\footnotetext{
Bronebakkot hivatkozza: Engbo (2017) 333.

Ploeg (2017) 303-305.

Report to the Storting, No. 37. (2007-2008) 9.

3 Federal Department of Justice and Police (2010) 10.
} 
fogalmazza meg külön alapelvként a bebörtönzés káros hatásai elleni küzdelmet, amely alapján minden erőfeszítést meg kell tenni annak megelőzése érdekében, hogy a fogvatartott ne izolálódjon a külvilágtól, így különösen engedélyezni kell számára - amenynyire csak lehetséges - az előnyös társadalmi kapcsolatokat.

A német büntetés-végrehajtási törvény ${ }^{24}$ 2. és 3 . szakasza alapján a bebörtönzés egyedüli célja képessé tenni a fogvatartottat, hogy a szabadulást követően felelősségteljes, bűnözéstől mentes életet éljen. Ennek megvalósítása pedig a jogszabály alapján igényli, hogy a börtönbeli élet, amennyire csak lehetséges legyen hasonló a szabad élettel, és egyúttal olyan módon kerüljön megszervezésre, amely megkönnyíti, előmozdítja a társalomba történő reintegrációt.

Hazánkban a Bv. kódex 83. §-ának (4) bekezdése alapján törekedni kell arra, hogy az elítélt életkörülményei közelítsenek a szabad élet általános körülményeihez, és ezáltal a szabadságvesztés káros hatásai enyhíthetők, illetve ellensúlyozhatók legyenek. A törvényhely alapján a szabad élet általános körülményeihez való közelítés során a keretet, avagy a korlátot egyrészt a fogva tartó intézet rendje és biztonsága, másrészről pedig a szabadságvesztés végrehajtási fokozata jelöli ki. A bíróság ítéletében meghatározott, illetve a büntetés-végrehajtási bíró által esetlegesen megváltoztatott végrehajtási fokozaton belül ugyanis a végrehajtás rendje, az elítélt részére adható kedvezmények az egyes fokozatokhoz kapcsolódó rezsimszabályok szerint eltérőek lehetnek.

Honi viszonylatban megemlíthető továbbá az atipikus normalizáció, mivel a szabad élethez való közelítés abban is megnyilvánul, hogy a fogvatartottak ne kerüljenek indokolatlanul kedvezőbb helyzetbe a szabad polgárokkal szemben. Erre tekintettel rendelkezik a Bv. törvény arról, hogy bizonyos többletszolgáltatásokat (például a kondicionáló terem használatát) a fogvatartottak is csak pénzbeli ellentételezéssel vehetnek igénybe.

\section{A normalizáció elve a gyakorlatban}

A téma szempontjából megkerülhetetlen kérdés, hogy az elvet az egyes államok hogyan érvényesítik a gyakorlatban? Kiindulásképpen a normalizáció érvényesítése/érvényesülése szempontjából nem szabad figyelmen kívül hagyni, hogy a börtönök világa és a szabad társadalom számos szempontból eltér egymástól. Amíg ugyanis a szabad társadalomban nem kifejezetten tiltott magatartások megengedettnek tekinthetők, addig a végrehajtási közegben minden, ami nem kifejezetten megengedett, az tulajdonképpen tiltott. A börtönkörnyezet emellett számos olyan tilalmat generál, amely a szabad életben fel sem merül, így gondolhatunk például az óvszerek, a testékszerek használatának kérdéskörére, vagy a tetoválások alkalmazására, újabban az internethasználat problematikájára. Hammerl a végrehajtási intézetek építészeti megoldásai, belső kialakítása kapcsán utal arra, hogy noha számos nyitott végrehajtási intézet egyre kevésbé hasonlít börtönre, a modern dizájn sem tudja csillapítani börtönérzetet,

24 Strafvollzugsgesetz of 1977. 
azaz a szabadságkorlátozó funkció sértetlen marad. ${ }^{25} \mathrm{~A}$ már többször hivatkozott Engbo a normalizációt vizsgálva egyenesen odáig jutott el, hogy szerinte magát a normalizáció szót is jobb kifejezés híján használjuk, hiszen hogyan lehet valami normális egy olyan személy számára, akit megfosztottak valami annyira természetestől/normálistól, mint a mozgási szabadsága? ${ }^{26}$

Kérdés lehet tehát, hogy hol, milyen cselekmények tekintetében húzhatók meg az alapelv határai? E kérdés megválaszolása ugyanakkor nagyon összetett, azt ugyanis számos tényező, így például a nemzetközi és regionális emberi jogi standardok, az adott társadalom fejlettségi szintje, a punitív szemlélet több esetben tapasztalható felerősödése egyaránt befolyásolhatják. Az alapelv így kétségtelenül relatív jellegü, hiszen nem lehet azonos standardokat érvényesíteni az egyes országokban. Ebből adódóan a normalizáció érvényesülése kapcsán mindig az adott ország viszonyait, fejlettségét kell irányadónak tekinteni és a szabad társadalomhoz képest, ahhoz viszonyítva lehet megkísérelni a „normalitás” értelmezését.

Talán nem meglepő, hogy az alapelv gyakorlatba történő legszemléletesebb átültetése a társadalmi és gazdasági biztonságukról híres skandináv jóléti országokhoz köthető, amelyek az 1970-es évek óta egyre nagyobb mértékben jelenítik meg végrehajtási politikájukban a normalizáció koncepcióját. Ez érhető tetten például abban, hogy a fogvatartottaknak szavazati joguk van a helyi, illetve a parlamenti választásokon; vagy a többi polgárral azonos jogok illetik meg őket a középfokú oktatásban, az egészségügyi ellátások, a társadalombiztosítás, a vallásszabadság tekintetében. Egyrészről tehát a jogi státuszuk sok szempontból nem tér el lényegesen a szabad polgárok helyzetétől, másrészről pedig a számukra biztosított humánus végrehajtási környezet (többek között a zárkák mérete, a börtönlét minősége, a nyitott intézetek térnyerése) ugyancsak a szabad életkörülményekhez közelítést célozza. Ennek köszönhető, hogy gyakorta az elvet és annak alkalmazását is a skandináv országokhoz kapcsolják.

Dániában a normalizáció olyan sajátosságokban nyilvánul meg, amelyek számos börtönrendszer számára elképzelhetetlenek: így utalhatunk arra, hogy a fogvatartottak és a személyi állomány tagjai a keresztnevükön szólítják egymást; az őr kopog, mielőtt belépne a fogvatartott zárkájába; a személyi állomány egyenruhája nem katonai jellegű, és a „furcsaságok” sorában megemlíthető a férfiakat és nóket együttesen fogva tartó végrehajtási gyakorlat ${ }^{27}$ is. Utóbbi esetében a női fogvatartottak maguk dönthetik el, hogy a férfi vagy a női lakóegységben kérnek elhelyezést, de a munkavégzés során a vegyes összetétel érvényesül. ${ }^{28}$

\footnotetext{
25 Hammerl (2018) 260-262.

26 Engbo szerint az elv lényegét jobban visszaadná a „demokratizáció” kifejezés, ami egyrészről utalna arra, hogy a börtönrezsim jogszabályon alapul, amelyet a polgárok által választott parlament fogadott el (demokrácia). Másrészről pedig kifejezné, hogy a fogvatartottaknak a többi polgárral azonos alapvető polgári szabadságjogaik vannak.

27 A vegyes nemi összetételű börtönök gyakorlata Dániában 2000 óta elfogadott, miután az egyetlen női végrehajtási intézetet rossz állapota miatt bezárták. Kétségtelen, hogy ez a gyakorlat jobban tükrözi a valós életet, mint a kizárólag nőket fogva tartó megoldás, másrészről azonban a fogvatartott nők alacsony aránya miatt sérti a nemek közötti egyenlőség elvét. E témáról bővebben: Mathiassen (2017) 377-403.

28 Minke (2017) 388.
} 
Ugyancsak figyelemreméltó, hogy 1976 óta alkalmazzák az önellátó élelmezés rendszerét, amelynek lényege, hogy a közösségi konyhában a fogvatartottak egyénileg vagy közösen készítik el saját ennivalójukat a börtönboltokban általuk megvásárolt élelmiszerekből. A normalizációra törekvés figyelhető meg abban is, hogy a nyitott végrehajtási intézetek nagyfokú mozgási szabadságot biztosítanak az elítélteknek, lévén a fogvatartási helyet családlátogatás, orvosi vizsgálat, illetve munkába vagy iskolába járás miatt elhagyhatják, de megemlíthető a saját ruha viselésének jogosultsága is. ${ }^{29}$

Jens Tolstrup ${ }^{30}$ a dán börtönök mindennapi életét a fenti jegyek alapján egyenesen polgári jellegúnek minősíti és visszautal arra, hogy a legtöbb dániai fogvatartott nyitott végrehajtási intézetben tölti büntetését, ahol könnyebb a szabad életkörülmények adaptálása. A fogvatartottakat megillető polgári jogok közül Tolstrup kiemeli a szavazati jogot a választások, illetve a politikai testületek tekintetében; a verbális, valamint írásban történő önkifejezés jogát; bármely egyesülés, társulás tagságához való jogot; a tulajdonhoz és a vallásgyakorláshoz való jogot, amelyek az emberi jogok biztosításának alapelvéből fakadtak. A dán modell így megtestesíti azt a felvetést, hogy egyetlen börtönrendszer sem szeparálódhat el attól a szociális/társadalmi valóságtól, amely körülveszi, és többé-kevésbé vissza kell tükröznie a szabad világ feltételeit.

Engbo a dániai normalizáció egy sajátos dimenziójáról is beszámol tanulmányában. Az eset lényege, hogy az egyik újonnan átadott büntetés-végrehajtási intézet a fogvatartottak számára nem épített saját templomot, így az elítéltek a vallásgyakorlás jogát a szabad polgárokkal közösen gyakorolhatták a helyi templomban. Mivel a fogvatartottak igényelték a lelkipásztorral való korlátlan kapcsolattartás jogát, mégpedig akként, hogy az ne legyen függvénye a börtönhatóság engedélyének és a templomba járásra ne a személyi állomány kíséretében kerüljön sor, a püspökhöz fordultak egy saját templom kérésével. Miután a templomot megkapták, a börtön kereste meg a helyi közösséget és invitálta a lakosságot az istentiszteletek közös látogatására. ${ }^{31}$

Linda Kjær Minke és kollégáinak tanulmánya ${ }^{32}$ többek között azt taglalja, hogy a normalizáció elvének a belga végrehajtási törvényben történő lefektetése ellenére egyes intézetek azt nem ültették át a gyakorlatba, míg másoknak sikerült fokozatosan normalizálniuk a rezsimet. A kutatók arra keresték a választ, hogy az elv érvényesülése miképpen jelenik meg a fogvatartottak élelmezése kapcsán. Az 5 végrehajtási intézetre kiterjedő kutatásban 4 intézetnél a rabok előre elkészített ételt kaptak a zárkájukba, míg az utolsónál a fogvatartottak elégedetlensége nyomán vezették be az önellátó rendszert. Ennek oka volt egyebek mellett a multikulturális börtönkörnyezet, amely így biztosítva látta a kulturális szokásokat követő étkezést. A fogvatartottakkal, illetve a személyi állománnyal készített interjúkból a kutatók egyrészről azt a következtetést vonták le, hogy az önellátó szisztémánál az őrök támogatták a fogvatartottak önállóságát,

\footnotetext{
29 Reiter et al. (2017) 486-490.; Dániában a nyitott börtönök és a normalizáció térnyerése szorosan összekapcsolódott. Vö.: Fransen (2017) 81-102.

30 Tolstrup (2002) 40.

31 Engbo (2017) 346-347.

32 Minke et al. (2016) 318-319.
} 
ami elősegítette a normalizáció érvényesülését, szemben a vizsgálatba vont többi börtönnel, ahol a biztonsági intézkedések akadályozták a normalizációt. Emellett építészeti szempontból a konyhák felállítása és a túlzsúfoltság hiánya egy relatíve pozitív környezetet eredményezett, amely ugyancsak a normalizációt támogatta.

Yngve Hammerlin ${ }^{33}$ megközelítésében a normalizáció alapelvéből a norvég büntetés-végrehajtási szolgálatra két feladat hárul: egyrészről a börtönfeltételeknek a külvilághoz közelítése, másrészről pedig olyan feltételek megteremtése, amelyek lehetővé teszik, hogy az egyes fogvatartottak megváltoztassák életmódjukat, elkerüljék a viszszaesést, „normalizálódjanak”. A normalizáció így a közösség, illetve az egyén szintjén is értelmezhető. A közösség szintjén olyan szolgáltatások biztosítását jelenti a börtönkörnyezetben, amelyek a szabad társadalomban is fellelhetők. Ezek lehetnek többek között az elítéltek foglalkoztatásához, oktatásához, egészségügyi ellátásához kapcsolódóak. A normalizáció a fogvatartottak egészségügyi ellátása kapcsán például azt jelenti, hogy a fogvatartottak számára biztosított egészségügyi ellátásnak legalább olyan szinten kell nyugodnia, mint ami a szabad világban irányadó. ${ }^{34}$ Az oktatásról szóló törvény, illetve a büntetés-végrehajtási törvény alapján pedig az ingyenes középfokú oktatás jogát a fogvatartottak magukkal hozzák a végrehajtási intézetbe, aminek biztosítása egyúttal a másik oldalról a végrehajtó és az oktatási hatóság kötelezettségét teremti meg. ${ }^{35} \mathrm{Az}$ oktatáshoz való jog Norvégiában a felnőttkorú fogvatartottakra is vonatkozik, amennyiben az alap- vagy a középfokú tanulmányaikat nem fejezték be, aminek szükségességét igazolja, hogy a börtönnépesség hozzávetőleges kétharmada 25 éves, vagy annál idősebb. ${ }^{36}$

A fogvatartottak joghelyzetének elismerését, a normalizáció szemléletét példázza az is, hogy amíg a norvég Büntetés-végrehajtás egy 2005-ös kiadványa úgy tekint a fogvatartottakra, mint olyan polgárokra, akiknek joguk van az oktatáshoz, addig Anglia és Wales Oktatási Minisztériumának a hasonló tárgyú dokumentuma bűnelkövetőkről beszél, akik érintettek az oktatásban. ${ }^{37}$

Az egyén szintjén, visszautalva a leírtakra, a normalizáció arra irányul, hogy a fogvatartott képes legyen alakítani saját életét, képes legyen a személyes fejlődésre.

Thomas Ugelvik több írásában ${ }^{38}$ is norvégiai rendszer meghatározó elemeként jellemzi a normalizációt és az elv érvényesülését összekapcsolja az úgynevezett import-/ importálási modellel. Értelmezésében a normalizáció mögött kettős logika húzódik meg. Egyrészről ugyanis a bebörtönzés, a szabadságelvonó ítélet nem vonja el az egyén jogait: megmarad például a szavazati jog, a jóléti állam által biztosított jóléti szolgáltatásokhoz

33 Hivatkozza: Engbo (2017) 332.

34 Ezt az elvet fogalmazza meg a Kínzás Elleni Európai Bizottság (CPT) 3. Általános Jelentésében, amikor kimondja, hogy a börtön-egészségügyi szolgálatnak biztosítania kell(ene) mindazon egészségügyi ellátást, kezeléseket, megfelelő diétát, pszichoterápiát, rehabilitációt és minden más szükséges lehetőséget, amelyet a betegek élveznek a kinti társadalomban. CPT/Inf (93)12. és The CPT standards. „Substantive” sections of the CPT's General Reports. CPT/ Inf/E (2002) 1-Rev. 2006.

35 Scharff Smith-Ugelvik (2017) 518.

36 Langelid (2015) 1-2.

37 Langelid (2017) 241.

38 Ugelvik (2016); Ugelvik (2017) 410-411. 
(ingyenes egészségügyi ellátáshoz, szociális szolgáltatásokhoz, középfokú oktatáshoz) való jogosultság. Másrészről az alapelv nyomán a börtön olyan életfeltételeket kreál, amelyek amennyire csak lehetséges, közelítenek az intézeten kívüli szabad, normális élethez, ezzel elősegítve, hogy felkészítsék az elítélteket arra a közegre, környezetre, ami őket a szabadulás után várja. Ennek kapcsán pedig biztosítani kell, hogy az átmenet, az átállás a lehető legkönnyebb és zökkenőmentesebb legyen. A gyakorlatban ennek lesz eszköze a már hivatkozott importmodell, amelynek lényege, hogy a büntetésvégrehajtás bizonyos szolgáltatásokat, mint például az egészségügyi ellátás, az oktatás, a kulturális és szociális szolgáltatásokat importálja a külső jóléti rendszertől. A börtönök egészségügyi rendszere így része a közegészségügyi rendszernek, a börtönoktatás a közoktatásnak, miként a börtönkönyvtárak a közkönyvtárak hálózatának. Ez egyúttal azt is jelenti, hogy az importált szolgáltatások egy részét nem maga a személyi állomány, hanem külső intézmények alkalmazottai (tanárok, egészségügyi dolgozók, könyvtárosok) látják el. ${ }^{39}$ Emellett az 1990-es évek óta néhány végrehajtási intézet, olyan személyeket is foglalkoztat, akiknek feladata a fogvatartottak szabadulás utáni munkakeresésének segítése. ${ }^{40}$

Az importmodellnek köszönhetően a norvég büntetés-végrehajtás így teljesen integrálódik a magas színvonalú nemzeti szociális rendszerbe. Ugelvik arról is beszámol, hogy a norvég kormány a közelmúltban egy úgynevezett „reintegrációs biztosítékot” épített ki annak érdekében, hogy a szabadulás után, ha az releváns, a szabadultnak munkát ajánljanak, megfelelő szállást biztosítsanak, továbbá oktatásban, egészségügyi ellátásban, függőséget gyógyító kezelésben való részvételét támogassák.

\section{Zárszó helyett}

A fentiekből kitûnően az európai börtönügy meghatározó alapelveként elkönyvelt normalizáció tényleges érvényre juttatása számos kérdést, problémát generál. Így az alapelv alkalmazása kapcsán felmerülő egyik lehetséges kérdés, hogy a normalizáció kinek a javára domináljon. Az önellátás sémáját követő dán modellnél például azon elítéltek számára, akik életük jelentôs részét töltötték büntetés-végrehajtási intézetben sok esetben az intézet által biztosított élelem és élelmezés a normális. Ebben a helyzetben egyesek szerint kényszeríteni kellene a fogvatartottakat, hogy megtanulják, miként lehet egészségesen főzni, míg mások, így például Engbo szerint ez már nem normalizáció lenne, hanem kényszerrel történő oktatás. A dán megoldás végül is a fogvatartottakra bízza annak eldöntését, hogy mi számukra a normális, az önellátás vagy az intézmény általi élelmezés. ${ }^{41}$

Hasonlóképpen kérdés lehet, hogy a börtönkörnyezet kövesse-e a szabad társadalomban fellelhető egyenlőtlenséget és eltéréseket, vagy törekedjen azok kiküszöbölésére? Ennek alátámasztására Engbo a svéd és a dán modellt ütközteti egymással

\footnotetext{
Ploeg (2017) 305.

Langelid (2017) 240-241.

$41 \quad$ Engbo (2017) 344.
} 
a fogvatartottak saját ruha viselésének joga kontra formaruha viselési kötelezettség kapcsán. Azzal ugyanis, hogy Dániában a fogvatartottak jogosultak a saját ruhájuk viselésére, szükségszerúen kiütközhetnek az egyes fogvatartottak közötti vagyoni különbségek. Az egyenlőség érvényesítésének elvét ezért érthetően a svédek formaruha viselési rendelkezése testesíti meg. ${ }^{42}$ Dirk van Zyl Smit és Sonja Snacken ${ }^{43}$ szerint a társadalmi egyenlőtlenségek megléte ismeretében a börtönkörnyezetben egy átlagos életszínvonalat kellene biztosítani és a fogvatartottak közötti extrém eltérések semmiképpen sem fogadhatók el.

A normalizációban rejlő pozitívumok hangoztatása mellett mindenképpen szükséges utalni arra, hogy a tényleges végrehajtási helyzet korlátokat állíthat, illetve állít az alapelv realizálása elé, tekintettel például arra, hogy a biztonsági megfontolások a végrehajtási közegben egyértelmű elsőbbséget élveznek. Mindamellett a globalizáció olyan termékei, mint az internet, a közösségi média, az elektronikus könyvek használata is kiszorul erről a területről. Erre tekintettel fogalmaz úgy Ploeg, hogy az az idea, miszerint a bebörtönzés csak a személyi szabadság elvonását jelentheti, már nem állja meg a helyét. Miként arra több szerző is rávilágít, ${ }^{44}$ a büntetéssel együtt járó társadalmi kirekesztés egyúttal digitális kirekesztéshez is vezet, ez pedig állandósítja és súlyosbítja az egyén társadalmi kirekesztettségét, a börtönkörnyezet és a társadalom közeledése helyett eltávolodásuk új szintre lép, Engbo megfogalmazásával élve az abnormalizáció napról napra nő. ${ }^{45}$ Peter Scharff Smith ${ }^{46}$ példaként arra utalt, hogy Dániában 2010-ben a lakosság 68\%-a használt internetet a közigazgatási eljárások során, amelynek alkalmazása a hatóságokkal való ügyintézésben előbb-utóbb mindenki számára kötelezővé válik. Amennyiben a fogvatartottak ki is kerülnek ezen rendelkezés hatálya alól, az internethasználattal összefüggő tudás, készségek elsajátítása számukra is alapvető fontosságú lenne.

A gyakorlati megvalósítás során jelentkező problémák ellenére számos olyan kezdeményezés fedezhető fel a börtönkörnyezetben, amely a közelítést és ezáltal a sikeres be-/visszailleszkedést szolgálja. Itt utalhatunk többek között a humánus életkörülményeket megtestesítő építészeti megoldásokra (festett falak, kényelmes bútorok, szép kilátás), ${ }^{47}$ az elektronikus levelezés megjelenésére, az állattartás lehetőségére, ${ }^{48}$ vagy éppen a belgák úgynevezett prison cloud-modelljére. Mindemellett alapvető jelentősége van a külvilággal való kapcsolattartás fenntartásának, a családi kötelékek ápolásának, ahogy a normalizáció elvének fontos szegmense a lakóhelyhez közeli végrehajtási intézetben elhelyezés kívánalma is.

\footnotetext{
Engbo (2017) 345.

Van Zyl Smit - Snacken (2009) 105.

Vö.: Jewkes (2009); Scharff Smith (2012); Warren (2007)

Engbo (2017) 347.

Scharff Smith (2012) 467.

Lásd például: Fridhov-Grøning (2018) 269-286.

E témához lásd például: Minke (2017) 387-395.
} 


\section{IRODALOMJEGYZÉK}

Engbo, Hans Jørgen (2017): Normalisation in Nordic prisons - from a prison governor's perspective. In Scharff Smith, Peter - Ugelvik, Thomas eds.: Scandinavian penal history, culture and prison practice. Embraced By the Welfare State?. UK, Palgrave Macmillan. 327-352.

Federal Department of Justice and Police (2010): The execution of sentences and measures in Switzerland. An overview of the system and execution of sentences and measures in Switzerland for adults and juveniles.

Fransen, Peter (2017): The rise of the open prisons and the breakthrough of the principle of normalisation from the 1930s until today. In Scharff Smith, Peter - Ugelvik, Thomas eds.: Scandinavian penal history, culture and prison practice. Embraced By the Welfare State?. UK, Palgrave Macmillan. 81-102.

Fridhov, Inger Marie - Grøning, Linda (2018): Penal Ideology and Prison Architecture. In Fransson, Elisabeth - Giofrè, Francesca - Johnsen, Berit eds.: Prison architecture and humans. Cappelen Damm Akademisk. 269-286.

Hammerl, Yngve (2018): Materiality, topography, Prison and 'Human turn'- A theoretical Short Visit. In Fransson, Elisabeth - Giofrè, Francesca - Johnsen, Berit eds.: Prison architecture and humans. Cappelen Damm Akademisk. 241-266.

Jewkes, Yvonne (2009): The role of the Internet in the Twenty-First-Century Prison: Insecure Technologies in Secure Spaces. In Aas, Katja Franko - Gundhus, Helene Oppen - Lomell, Heidi Mork eds: Technologies of InSecurity. The Surveillance of Everyday Life. Routledge. 171-189.

Langelid, Torfinn (2015): Old codgers going on about the past... and the future! Forgotten innovations in the history of prison education. Antwerpen, EPEA conference 2015.

Langelid, Torfinn (2017): The development of education in Norwegian prisons. In Scharff Smith, Peter - Ugelvik, Thomas eds.: Scandinavian penal history, culture and prison practice. Embraced By the Welfare State?. UK, Palgrave Macmillan. 225-247.

Mathiassen, Charlotte (2017): Being a woman in a mixed-gender prisons. In Scharff Smith, Peter Ugelvik, Thomas eds.: Scandinavian penal history, culture and prison practice. Embraced By the Welfare State?. UK, Palgrave Macmillan. 377-403.

Minke, Linda Kjær et al. (2016): Multiple perspectives on imprisonment in Europe. Nordisk Tidsskrift for Kriminalvidenskab, Vol. 103, No. 3.311-333.

Minke, Linda Kjær (2017): Normalization, social bonding and emotional support - A dog's effect within a prison workshop for women. Anthrozoös, Vol. 30, No. 3. 387-395.

Ploeg, Gerhard (2017): Scandinavian acceptionalism? Developments in community. In Scharff Smith, Peter - Ugelvik, Thomas eds.: Scandinavian penal history, culture and prison practice. Embraced By the Welfare State?. UK, Palgrave Macmillan. 297-324.

Reiter, Keramet et al. (2017): Negotiating imperfect humanity in the Danish penal system. In Scharff Smith, Peter - Ugelvik, Thomas eds.: Scandinavian penal history, culture and prison practice. Embraced By the Welfare State?. UK, Palgrave Macmillan. 481-508.

Scharff Smith, Peter (2012): Imprisonment and Internet-Access. Human Rights, the Principle of Normalization and the Question of Prisoners Access to Digital Communications Technology. Nordic Journal of Human Rights, No. 4.

Scharff Smith, Peter - Ugelvik, Thomas (2017): Punishment and welfare in Scandinavia. In Scharff Smith, Peter - Ugelvik, Thomas eds.: Scandinavian penal history, culture and prison practice. Embraced By the Welfare State?. UK, Palgrave Macmillan. 511-529.

Schartmueller, Doris (2015): Life imprisonment in Scandinavia: The ultimate punishment in the penal environments of Denmark, Finland, and Sweden. Northern Arizona University.

Tolstrup, Jens (2002): The Danish Prison Model. Normalisation, openness and responsibility. Track Two - Constructive Approaches to Community and Political Conflict, Vol. 11, No. 2. 39-41.

Ugelvik, Thomas (2016): Prisons as Welfare Institutions? Punishment and the Nordic Model. In Bennett, Jamie - Jewkes, Yvonne - Crewe, Ben eds.: Handbook on Prisons. London, Routledge. 
Ugelvik, Thomas (2017): The Limits of the Welfare State? Foreign National Prisoners in the Norwegian Crimmigration Prison. In Scharff Smith, Peter - Ugelvik, Thomas eds.: Scandinavian penal history, culture and prison practice. Embraced By the Welfare State?. UK, Palgrave Macmillan. 405-423.

Van Zyl Smit, Dirk - Snacken, Sonja (2009): Principles of european prison law and policy. Penology and human rights. Oxford, University Press

Warren, Martyn (2007): The digital vicious cycle: Links between social disadvantage an digital exclusion in rural areas. Telecommunications Policy, Vol. 31, No. 6-7. 374-388.

\section{Jogforrások}

CPT/Inf (93)12. és The CPT standards. „Substantive” sections of the CPT's General Reports. CPT/ Inf/E (2002) 1-Rev. 2006.

$\operatorname{Rec}(2003) 23 E$ / 9 October 2003 Recommendation of the Committee of Ministers to member states on the management by prison administrations of life sentence and other long-term prisoners.

Report to the Storting, No. 37. (2007-2008)

Response of the government of Denmark to note cu 2011/26., Forrás: www.unodc.org/documents/ justice-and-prison-reform/EGM-Uploads/DENMARK-GOV-13-En.pdf (2018. 05. 03.)

Standard Minimum Rules for the Treatment of Prisoners. Adopted by the First United Nations Congress on the Prevention of Crime and the Treatment of Offenders, held at Geneva in 1955, and approved by the Economic and Social Council by its resolutions 663 C (XXIV) of 31 July 1957 and 2076 (LXII) of 13 May 1977, 60 (1).

Resolution (73) 5 on the standard minimum rules for the treatment of prisoners.

Recommendation No. R (87)3 on the European Prison Rules.

Recommendation No. R (2006)2. European Prison Rules.

European Prison Rules. Council of Europe Publishing, Council of Europe, June 2006.

\section{ABSTRACT}

\section{The Principle(s) of Prison Law}

JUHÁSZ Zsuzsanna

The principle of the normalisation is a European human rights principle codified in the European Prison Rules and a core value of many countries, particularly all Scandinavian prison systems. The principle means that authorities must not interfere with prisoners' lives more than what is necessary in a prison environment and also requires authorities to actively create conditions which approach conditions on the outside whenever possible. In some interpretations the concept of normalisation also means that the prison authorities have to facilitate the individual inmate's endeavours to achieve his/her own normality while in prison. But which restrictions should be seen as inherent to the deprivation of liberty and what is to be considered normal in prison and outside society? This paper addresses these questions on the basis of theory and prison practices.

Keywords: normalization, basic principle, prison life, civil rights 